\title{
Factors Influencing University Students' Adoption of Digital Learning Technology in Teaching and Learning
}

\author{
Amer Mutrik Sayaf ${ }^{1}$, Mahdi M. Alamri ${ }^{2} \mathbb{D}$, Mohammed Ayid Alqahtani ${ }^{1}$ and Waleed Mugahed Alrahmi ${ }^{3, *}$ \\ 1 Educational Technology Department, College of Education, University of Bisha, Bisha 61922, Saudi Arabia; \\ abishi@ub.edu.sa (A.M.S.); mqahtani@ub.edu.sa (M.A.A.) \\ 2 Educational Technologies, King Faisal University, Hofuf 31982, Saudi Arabia; mahdi@kfu.edu.sa \\ 3 Faculty of Social Sciences and Humanities, School of Education, Universiti Teknologi Malaysia (UTM), \\ Skudai 81310, Johor, Malaysia \\ * Correspondence: waleed.alrahmi@yahoo.com
}

check for

updates

Citation: Sayaf, A.M.; Alamri, M.M.; Alqahtani, M.A.; Alrahmi, W.M. Factors Influencing University Students' Adoption of Digital Learning Technology in Teaching and Learning. Sustainability 2022, 14, 493. https://doi.org/10.3390/su14010493

Academic Editors:

Javier Cifuentes-Faura,

Joseph Crawford and Jo-Anne Kelder

Received: 11 November 2021

Accepted: 30 November 2021

Published: 4 January 2022

Publisher's Note: MDPI stays neutral with regard to jurisdictional claims in published maps and institutional affiliations.

Copyright: (c) 2022 by the authors. Licensee MDPI, Basel, Switzerland. This article is an open access article distributed under the terms and conditions of the Creative Commons Attribution (CC BY) license (https:// creativecommons.org/licenses/by/ $4.0 /)$.

\begin{abstract}
Education and learning have been significantly impacted by ICT. The purpose of this project is to create a new model and conduct confirmatory factor analysis in order to better understand how students utilize ICT in the classroom. An additional aim is to study, based on students' attitudes and aspirations to utilize ICT for digital learning, their fundamental computer abilities, mediarelated skills, WBS, and adoption of digital learning technologies, by surveying students at Bisha University and King Faisal University. Structural equations modeling (SEM)-AMOS was used to survey 711 university students, and this study used an improved version of the Technology Acceptance Paradigm (TAM) approach as its research paradigm, as well as quantitative data collection and analytic methodologies. Students' comments were divided into seven categories and analyzed to identify their attitudes toward and intentions for using ICT in learning environments. BCS, mediarelated abilities, and WBS all had a substantial influence on perceived usefulness and perceived ease of use, according to the research. This model, which was based on research, was successful in describing students' attitudes and intentions about using ICT for digital learning.
\end{abstract}

Keywords: adoption of digital learning; ICT; TAM; SEM

\section{Introduction}

Teachers are required to use ICT for both teaching and administration in today's educational institutions [1]. When it comes to technology adoption, they also act as change agents in their schools [2]. Teachers employ technology in two ways [3], one of which is to achieve the same traditional aims in the same settings without having to drastically alter classroom activities. The second method involves using technology into the classroom to break down barriers, connect students to real-world activities, and assist them in becoming self-sufficient learners. Teachers' views regarding teaching and learning are likely to influence how they use technology. Educators' views have the power to influence their teaching methods and classroom behavior. According to Hermans et al. [4], ICT play a mediating role in educators' acceptance of educational technologies. This involves framing how they arrive at such academic decisions such as lesson planning, implementation system, and evaluation approaches, as well as processes for ICT incorporation in the classroom. According to Munoz-Miralles et al. [5], advances in ICT have resulted in a variety of benefits, including new means of communication, function, and learning. They are particularly beneficial to universities in providing comprehensive and efficient training to students who will become technological specialists in the near future. Furthermore, experts [6] claim that the usage of ICT stimulates and engages pupils, making it one of the learning engines in education. Studying strategies are important in academic advancement since each student learns in a different way. Because students are constantly exposed to technology, they incorporate it into their studies in a variety of ways. As a result, the 
educational community has become more interested in how pupils learn in connection with their use of ICT, as indicated by research like $[7,8]$. The most fascinating feature of ICT, according to Yazon et al. [9], is how it can be employed in university education and how much it improves the learning process. The creation of questionnaires, such the research undertaken by [10] that examines potential teachers' ICT competencies, or as the one designed for teachers by [11] are two instances of this impact. The study's findings [12] suggest that in order to teach and do research, faculty members require ICT training. The perspectives of students on ICT are significant because they influence how they use technology, which has an impact on their academic and professional performance. A positive evaluation of ICT components does not guarantee that they will be employed in the learning process $[13,14]$, but it is a solid starting point. In many aspects of social life, but particularly in education, information and communication technologies are becoming increasingly common and vital. As a result of having a point of contact, students' training has changed. As Cabero points out, ICT is becoming an important component in the educational sector, allowing us to undertake demanding formative activities that are not possible with traditional technological approaches [15].

\section{Problem Background}

Learning must be implemented in a way that is collaborative between teachers and students. Teachers must also have the ability to incorporate technology into the classroom. Teachers must also be well-versed in the usage of ICT [16]. Students need to build 4C competencies, according to Wijaya et al. [17] (innovation and creativity are important, as are communication, teamwork, critical thinking, and problem-solving). As a result, the use of ICT and digital learning tools in planning is intrinsically related to the plan's learning model. In this study, we identify a gap in our knowledge of university students mandates and the role that digital learning can play [18]. As a result, students at all higher education institutions must have understanding of how to utilize ICT and digital learning technology in an educational setting, as well as learning and creativity abilities. As a consequence, this research provides a framework for investigating the link between students' ICT use and their digital learning. In impoverished nations, implementing and utilizing instructional technology has proven difficult, and it does not necessarily result in proportional improvements in student learning results. As a result, in order to improve university student results in terms of ICT use and digital learning technologies, it is required to investigate and analyze crucial success characteristics $[19,20]$. As a result, the study topic concentrates around educational technology and information systems' fast advancement. This research looked examined whether such advancements will aid developing countries like Bisha University and King Faisal University. As a consequence, this paper identifies and examines the factors that influence ICT usage and digital learning technologies among university students.

\section{Development of a Research Model and Hypothesis}

In higher education, information and communication technology (ICT) has transformed technology and learning. Adoption research has resulted in a variety of complementary and opposing study adoption models, the bulk of them have something to do with the adoption of information systems (IS), such as ICT. The Technology Acceptance Model (TAM) was designed by [21] and is now widely used by academics to assess the acceptance of new technologies. The following seven factors that impact the use of information and communication technology (ICT) for digital learning in the current study are: Students' basic computer abilities (BCS), media-related skills (MRS), web-based skills (WBS), perceived ease of use (PEU), perceived usefulness (PU), students' attitude toward usage (ATT), and students' plans to utilize ICT for digital learning (SIU), as depicted in Figure 1. 


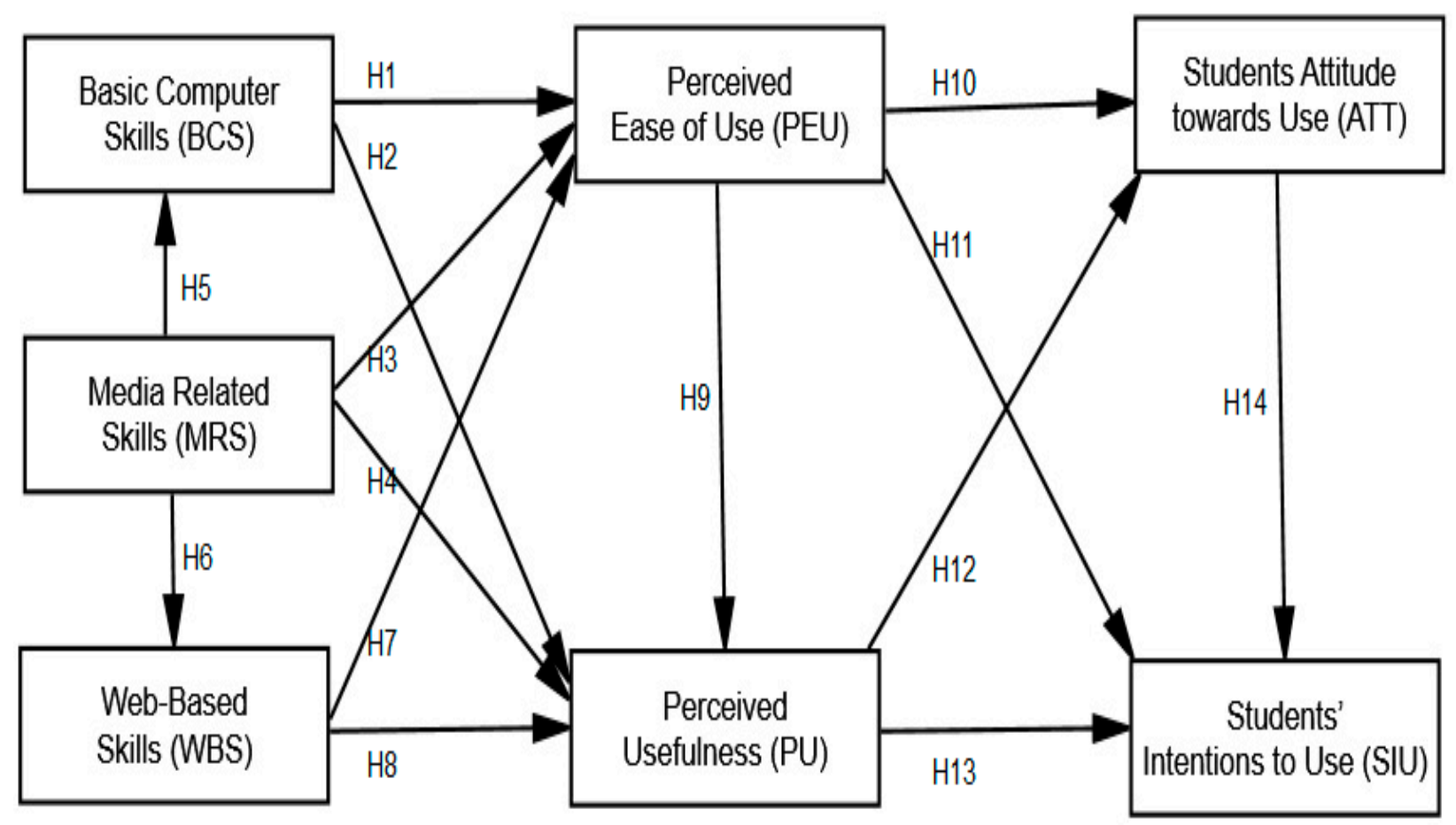

Figure 1. Research Model.

\section{1. $B C S$}

Computer skills come into both categories [22], as they may serve as the "content" of the work, especially in IT jobs, but they can also be considered as a technical competence that enhances non-IT employees' productivity. Student instructors with a science background use computer abilities more frequently than those with a humanities background [23]. Furthermore, prospective teachers who have access to a computer at home are more likely to use their computer skills than those who do not [23]. Software users have a big effect on students' judgments of computer skills. Individual expectations are influenced by trust in projected job opportunities, which is a factor in determining student competency [24]. When it comes to employing ICT for digital learning, the proposed hypothesis for this construct is that perceived usefulness and convenience impact fundamental computer abilities. As a result, the following hypotheses are proposed in this study.

Hypothesis 1 (H1). There is an important relationship between BCS and PEU.

Hypothesis $2 \mathbf{( H 2 ) . ~ T h e r e ~ i s ~ a n ~ i m p o r t a n t ~ r e l a t i o n s h i p ~ b e t w e e n ~ B S C ~ a n d ~ P U . ~}$

\section{2. $M R S$}

The defined atmosphere excuses pedagogical and academic reactions and viewpoints. In today's digital and media world, teachers must be able to instill in students the fundamental skills necessary for digital learning [25]. Given that students in the twenty-first century, known as digital natives [25], conduct their activities, correspondence, and knowledge management using modern communication and information technologies [26], defining the skills needed to use these technologies and managing their growth is critical [27]. MRS attitudes toward ICT use for digital learning are impacted by perceived usefulness and perceived ease of using ICT in learning environments, according to the presented hypothesis for this construct. As a result, the following hypotheses are proposed in this study.

Hypothesis 3 (H3). There is an important relationship between MRS and PEU. 
Hypothesis 4 (H4). There is an important relationship between MRS and PU.

Hypothesis 5 (H5). There is an important relationship between MRS and BCS.

Hypothesis 6 (H6). There is an important relationship between MRS and WBS.

\subsection{WBS}

The first characteristic of WBS is simplicity [28]. No extensive computer skills are needed. Digital literacy has been highlighted as a critical skill for instructors who are committed to providing high-quality online learning through WBS [29]. Brushing up on one's ICT awareness is an object need today for web-based skills, and educational institutions must also provide opportunities and retain these essential skills for digital learning to take place [30]. Student attitudes about web-based education were assessed using web-based learning skills, whose reliability and validity analyses were performed by [31]. WBS were easy to learn and helpful, suggesting that computer skills and time are not significant impediments to implementing WBS [32,33]. Instead of being distracted by distracting and often serious technical problems, teachers should focus on the core science concepts being taught. Many recent studies have found that smart teaching techniques must be combined with WBS [34]. The suggested hypothesis for this construct is that WBS towards ICT usage for digital learning is influenced by perceived usefulness and PEU of ICT for educational technology. As a result, the following hypotheses are proposed in this study.

Hypothesis 7 (H7). There is an important relationship between WBS and PEU.

Hypothesis 8 (H8). There is an important relationship between WBS and PU.

\subsection{PEU}

The degree to which a customer feels that utilizing an ICT is painless is referred to as PEU. People are more likely to have a favorable opinion of a technology if it looks to be simple to use $[35,36]$. PEU refers to a student's belief that utilizing ICT is both straightforward and useful in this subject [21,37]. PEU examines how technology affects performance processes, whereas PU examines how it boosts workplace productivity [21]. PEU of ICT for digital learning is impacted by PU, students' attitudes regarding usage, and students' intents to use ICT for digital learning, according to the presented hypothesis. As a result, the following hypotheses are proposed in this study.

Hypothesis 9 (H9). There is an important relationship between PEU and PU.

Hypothesis 10 (H10). There is an important relationship between PEU and ATT.

Hypothesis 11 (H11). There is an important relationship between PEU and SIU.

\subsection{PU}

PU [21] refers to one's belief that employing technology can improve one's job efficiency. In this study, PU refers to how much students feel ICT may help them learn more effectively through digital learning. Recent research $[36,38,39]$ has found that PU has an impact on students' attitudes regarding technology and motivation to utilize it. While PU has a direct influence on student satisfaction and intent to adopt ICT for digital learning, it is also considered to have an indirect impact. Students' attitudes toward ICT use for digital learning, as well as their plans to utilize ICT for digital learning, have a positive effect on PU, according to the presented hypothesis for this construct. As a result, the following hypotheses are proposed in this study. 
Hypothesis 12 (H12). There is an important relationship between PU and ATT.

Hypothesis 13 (H13). There is an important relationship between PU and SIU.

\subsection{Students' ATT}

Students' attitudes toward use are affected by their learning environment [40] or their attention to and approval of their educational activities [41], according to the literature. Consumer attitudes toward ICT use for digital learning are influenced by PEU and the TAM, according to Davis et al. [21], and when combined, consumer attitudes toward ICT use for digital learning are influenced. In a separate research [42,43], PEU and perceived usefulness were found as significant indicators for picking virtual courses. The PEU influences students' attitudes about utilizing ICT and their readiness to act. In this study, students' intention to use ICT for digital learning is described as students' view that utilizing ICT assists their education, which encourages students' desire to use ICT for digital learning. According to the hypothesis for this construct, students' attitudes toward utilizing ICT for digital learning are favorably influenced by their intentions to utilize ICT for digital learning. As a result, the following hypothesis is proposed in this study.

\section{Hypothesis 14 (H14). There is an important relationship between ATT and SIU.}

\subsection{Intentions of Students to Utilize ICT}

The students' goal the urge to use and continue to use technology is referred to as "to utilize ICT". Intentions to use ICT have a factor in students' technology usage [44]. A student's purpose for utilizing ICT in this research was to improve their love of learning. Technical growth utilization models $[21,37,45]$ contain a significant degree of learning via ICT. The word "intention to use" is used in the technology literature to describe a person's desire to utilize a technology in the not-too-distant future. Because of its consistency in anticipating real technology usage, it was chosen as an outcome variable in this study [36].

\section{Methodology of Study}

To assess the theoretical model and hypotheses that were proposed in Section 2, quantitative methods have been established, and this study employed a quantitative analytical survey. The measurement items were created from a literature review and were designed to cover all aspects of the construction process of the research model shown in Figure 1. Many institutions throughout the world, including Saudi Arabia, have advocated the use of ICT platforms as a way to ensure higher education's sustainability and survival. As a result, the purpose of this research is to use structural equation modeling (SEM) to construct a model for assessing students' actions in terms of their ATT and SIU. Undergraduate and postgraduate students who employed ICT for digital learning made up the study's sample. Many universities across the globe, including those in Bisha University and King Faisal University, have encouraged students to learn digitally through the use of widely available ICTs. As a result of an observational research of students' adoption of ICT for digital learning, this project intends to develop a model for measuring students' desire to use and appreciate technology. The study group consisted of undergraduate and postgraduate students who employed ICT for digital learning. A five-point Likert scale was employed for topics like TAM components and demo-graphic data, with 1 indicating strong disagreement and 5 suggesting strong agreement. Respondents were questioned about how ICT was used for digital learning, how it affected SIU ICT for digital learning, and how satisfied they were with the outcomes. Statistical Package for the Social Sciences (SPSS) and Structural Equation Modeling were used to confirm the measurement model's validity and reliability (AMOS-SEM). Factor loadings were used to determine construct validity, composite reliability, Cronbach's alpha, and convergence validity for the model's goodness of fit, as recommended by Hair et al. [46]. Based on standardized items, Cronbach's alpha 
was found to be 0.944 . The reliability coefficient (Cronbach's alpha) for both the pilot and final test designs is shown in Table 1: all variables were found to be accurate and sufficient. See Table 1 for further information.

Table 1. Reliability coefficients in the pilot and final tests for both constructs.

\begin{tabular}{|c|c|c|c|c|}
\hline No. & Latent Factors & Code & Pilot Test & Final Test \\
\hline 1 & Basic Computer Skills & BCS & 0.800 & 0.921 \\
\hline 2 & Media Related Skills & MRS & 0.791 & 0.909 \\
\hline 3 & Web-Based Skills & WBS & 0.821 & 0.885 \\
\hline 4 & Perceived Ease of Use & PEU & 0.773 & 0.892 \\
\hline 5 & Perceived Usefulness & PU & 0.760 & 0.911 \\
\hline 6 & $\begin{array}{l}\text { Students' Attitude } \\
\text { towards use ICT }\end{array}$ & ATT & 0.723 & 0.937 \\
\hline 7 & $\begin{array}{l}\text { Intentions to use ICT } \\
\text { for digital learning }\end{array}$ & SIU & 0.829 & 0.901 \\
\hline
\end{tabular}

\subsection{Data Collection and Sample Characteristics}

While institutions were closed due to the COVID-19 epidemic, this survey was done online from January to March 2021. A survey instrument was designed and evaluated before the major data collection to look at the factors that impact student usage of ICT for digital learning. As part of the study, we distributed 737 questionnaires. The responses of 26 people were excluded after the normality test, as advised by [46], who indicated that outliers might lead to erroneous statistical conclusions and should be removed. As a consequence, 711 participants' responses were loaded into the SPSS software program. Conducted during the COVID-19 outbreak, this study focuses on postgraduate and undergraduate students at Bisha University and King Faisal University who are active users of ICT for digital learning. Confirmatory factor analysis is performed to assess the model's validity.

\subsection{Instruments of Measurement}

The construction components used in prior research proved the measuring scales' material validity. The study questionnaire gathered basic demographic information (gender, age, educational level, and specialty) as well as questionnaire items that rated these traits. BCS were derived from [23], media-related skills were derived from [25], WBS were derived from [29], PEU were derived from [21], PU were derived from [21], students' attitudes were derived from [21], and intentions to use ICT for digital learning were derived from [21]. As a consequence, the factors were assessed using multi-item measures based on prior research and self-report. All of the variables were evaluated on a five-point Likert scale, with 1 representing "strongly disagree" and 5 representing "strongly agree". Table 2 has a complete list of everything.

Table 2. Item loadings, reliability, and validity of the measurement model.

\begin{tabular}{|c|c|c|c|c|c|}
\hline Factors & Code & Loading & AVE & CR & $\mathrm{CA}$ \\
\hline \multirow{5}{*}{ Basic Computer Skills } & BCS1 & 0.832 & \multirow{5}{*}{0.607} & \multirow{5}{*}{0.908} & \multirow{5}{*}{0.921} \\
\hline & $\mathrm{BCS} 2$ & 0.854 & & & \\
\hline & BCS3 & 0.821 & & & \\
\hline & BCS4 & 0.722 & & & \\
\hline & BCS5 & 0.763 & & & \\
\hline \multirow{4}{*}{ Media Related Skills } & MRS1 & 0.743 & \multirow{4}{*}{0.599} & \multirow{4}{*}{0.819} & \multirow{4}{*}{0.909} \\
\hline & MRS2 & 0.732 & & & \\
\hline & MRS3 & 0.782 & & & \\
\hline & MRS4 & 0.813 & & & \\
\hline \multirow{3}{*}{ Web-Based Skills } & WBS1 & 0.803 & \multirow{3}{*}{0.713} & \multirow{3}{*}{0.919} & \multirow{3}{*}{0.885} \\
\hline & WBS2 & 0.754 & & & \\
\hline & WBS3 & 0.753 & & & \\
\hline
\end{tabular}


Table 2. Cont.

\begin{tabular}{|c|c|c|c|c|c|}
\hline Factors & Code & Loading & AVE & CR & CA \\
\hline \multirow{5}{*}{ Perceived Ease of Use } & PEU1 & 0.723 & \multirow{5}{*}{0.665} & \multirow{5}{*}{0.898} & \multirow{5}{*}{0.892} \\
\hline & PEU2 & 0.793 & & & \\
\hline & PEU3 & 0.773 & & & \\
\hline & PEU4 & 0.771 & & & \\
\hline & PEU5 & 0.781 & & & \\
\hline \multirow{5}{*}{ Perceived Usefulness } & PU1 & 0.721 & \multirow{5}{*}{0.703} & \multirow{5}{*}{0.902} & \multirow{5}{*}{0.911} \\
\hline & PU2 & 0.832 & & & \\
\hline & PU3 & 0.792 & & & \\
\hline & PU4 & 0.753 & & & \\
\hline & PU5 & 0.770 & & & \\
\hline \multirow{4}{*}{ Students' Attitude towards use ICT } & ATT1 & 0.832 & \multirow{5}{*}{0.642} & \multirow{4}{*}{0.910} & \multirow{4}{*}{0.937} \\
\hline & ATT2 & 0.882 & & & \\
\hline & ATT3 & 0.741 & & & \\
\hline & ATT4 & 0.862 & & & \\
\hline \multirow{3}{*}{ Intentions to use ICT for digital learning } & SIU1 & 0.811 & & \multirow{3}{*}{0.895} & \multirow{3}{*}{0.901} \\
\hline & SIU2 & 0.820 & \multirow[t]{2}{*}{0.697} & & \\
\hline & SIU3 & 0.863 & & & \\
\hline
\end{tabular}

\section{Analysis and Findings}

Covariance-based structural equation modeling was used to analyze the thesis' conceptual model (CB-SEM). CB-SEM provides a number of benefits. The parameters were estimated using the maximum likelihood (ML) method [46]. The AMOS program and the CB-SEM technique were used to assess the data (v.24). As methodological measures, the calculating model and the structural model were both assessed. The structural model considers how ICT may be used to evaluate digital learning hypotheses, whereas the measurement model considers construct reliability, validity, and overall model fitness.

\subsection{Details on the Population}

Table 3 shows the demographic information. Among the 711 useable questionnaires polled, 439 female respondents $(61.7 \%)$ were found, while 272 male respondents were found $(38.3 \%)$. Furthermore, 236 respondents $(33.2 \%)$ were between the ages of 18 and 21 , $180(25.3 \%)$ were between the ages of 22 and $25,98(13.8 \%)$ were between the ages of 26 and $29,62(8.7 \%)$ were between the ages of 30 and 33 , and $135(19.0 \%)$ were over the age of 34 . In addition, 356 respondents (50.1\%) from Bisha University and 355 respondents (49.9\%) from King Faisal University participated in the survey. Regarding level of education: $348(48.9 \%)$ were undergraduate students, while $363(51.1 \%)$ were postgraduate students. Members of the faculty included 307 (43.2\%) members of the faculty of education, $84(11.8 \%)$ members of the faculty of science, $261(30.4 \%)$ members of the faculty of art and humanities, $43(6.0 \%)$ members of the faculty of medical science, and $61(8.6 \%)$ members of the faculty of computer science. According to the research, 420 respondents (59.1\%) were full-time students, while 291 (40.9\%) were part-time students. Regarding period of ICT use for digital learning: 357 respondents $(50.2 \%)$ had only used ICT for five years or less, 218 respondents $(30.7 \%)$ had used ICT for five to ten years, and 136 respondents $(19.1 \%)$ had used ICT for more than 10 years. Finally, information and communication technology (ICT) may be employed for digital learning; 487 people (68.5\%) said they used ICT for digital learning all of the time, 202 people $(28.4 \%)$ said they used it part of the time, and 22 people $(3.1 \%)$ said they did not use it at all. 
Table 3. Demographic data.

\begin{tabular}{|c|c|c|c|c|c|c|c|}
\hline \multicolumn{2}{|r|}{ Factors } & \multirow{2}{*}{$\begin{array}{c}\mathbf{N} \\
439\end{array}$} & \multirow{2}{*}{\begin{tabular}{|c|}
$\%$ \\
61.7
\end{tabular}} & \multicolumn{2}{|r|}{ Factors } & \multirow{2}{*}{$\frac{\mathbf{N}}{356}$} & \multirow{2}{*}{$\begin{array}{c}\% \\
50.1\end{array}$} \\
\hline \multirow[b]{2}{*}{ Gender } & Female & & & \multirow[b]{2}{*}{ University } & Bisha University & & \\
\hline & Male & 272 & 38.3 & & $\begin{array}{l}\text { King Faisal } \\
\text { University }\end{array}$ & 355 & 49.9 \\
\hline \multirow{5}{*}{ Age } & 18-21 years & 236 & 33.2 & \multirow{5}{*}{ Faculties } & Education & 307 & 43.2 \\
\hline & $22-25$ years & 180 & 25.3 & & Science & 84 & 11.8 \\
\hline & $26-29$ years & 98 & 13.8 & & Art and humanities & 261 & 30.4 \\
\hline & 30-33 years & 62 & 8.7 & & Medical science & 43 & 6.0 \\
\hline & More than 34 years & 135 & 19.0 & & Computer science & 61 & 8.6 \\
\hline \multirow{3}{*}{$\begin{array}{c}\text { Level of } \\
\text { education }\end{array}$} & Undergraduate & 348 & 48.9 & \multirow{2}{*}{ Type of study } & Full time & 420 & 59.1 \\
\hline & Postgraduate & 363 & 51.1 & & Part time & 291 & 40.9 \\
\hline & Less than 5 years & 357 & 50.2 & \multirow{3}{*}{ Use ICT } & Always & 487 & 68.5 \\
\hline \multirow{2}{*}{$\begin{array}{l}\text { Time of } \\
\text { use ICT }\end{array}$} & 5-10 years & 218 & 30.7 & & Sometimes & 202 & 28.4 \\
\hline & More than 10 years & 136 & 19.1 & & Does not use & 22 & 3.1 \\
\hline
\end{tabular}

\subsection{Reliability, Validity, and Measurement Model Interventions}

The SEM-AMOS measurement model for each idea has its own set of characteristics, such as reliability and validity. Individual CFA and model fitness indicators from the measurement model were utilized to examine the intensity of the link direction using the structural model. Table 2 lists the components of the measurement. Because the majority of the commodities meet the needed 0.707 level, the results show that item dependability is not an issue [46]. The constructs' internal consistency was assessed using composite reliability, which varied from 0.819 to 0.919 and was greater than the cut-off value of 0.70 [46]. The constructs' average variance derived (AVE) varied from 0.713 to 0.599 , much over the 0.50 requirement, indicating convergent validity [46]. To assess discriminant validity, researchers employed cross-loading, the square-root of AVE (Fornell and Larcker ratio), ASV, and MSV tests. The diagonal value is greater than the values of the adjacent row and column numbers (values are bold shown in Table 4). It denotes a stronger connection between the structure and its surroundings. The maximum shared variance (MSV) is less than the average absolute variance (AVE) in the same way that the average shared variance (ASV) is less than the average absolute variance (AVE) (Table 4).

Table 4. Discriminant validity.

\begin{tabular}{cccccccccccc}
\hline Factors & Code & AVE & MSV & ASV & MRS & WBS & BCS & PEU & PU & ATT & BIU \\
\hline Media Related Skills & MRS & 0.599 & 0.217 & 0.082 & 0.849 & & & & & \\
Web-Based Skills & WBS & 0.713 & 0.091 & 0.071 & 0.399 & 0.897 & & & & \\
Basic Computer Skills & BCS & 0.607 & 0.082 & 0.052 & 0.328 & 0.403 & 0.815 & & & \\
Perceived Ease of Use & PEU & 0.665 & 0.210 & 0.067 & 0.209 & 0.203 & 0.199 & 0.851 & & \\
Perceived Usefulness & PU & 0.703 & 0.230 & 0.062 & 0.219 & 0.246 & 0.257 & 0.267 & 0.856 & \\
Attitude towards use & ATT & 0.642 & 0.051 & 0.032 & 0.291 & 0.366 & 0.344 & 0.268 & 0.341 & 0.871 \\
Intentions to use ICT & BIU & 0.697 & 0.120 & 0.041 & 0.216 & 0.316 & 0.322 & 0.278 & 0.330 & 0.384 & 0.927 \\
\hline
\end{tabular}

\subsection{Model Fit Assessment}

The CMN/DF ratio in Table 5 is 4.333, which is lower than the necessary threshold (5.00). The GFI (0.947) is an excellent place to start, but the CFI (0.953), TLI (0.921), and IFI (0.930) are all above average as well. The badness measures of the model were sufficient, with RMR and RMSEA values below the threshold of $0.48(0.05)$ and $0.036(0.08)$, respectively [46]. Figure 2 depicts the whole set of observations. This shows that the measurement model was acceptable and well-suited to the structural model. 
Table 5. Results hypotheses testing.

\begin{tabular}{ccccccccc}
\hline & Hypotheses \& Path & & Beta $(\boldsymbol{\beta})$ & Standard Error & Critical Ratio & $p$-Value & Result \\
\hline Hypothesis 1 & PEU & $<-$ & BCS & 0.223 & 0.040 & 5.576 & 0.000 & Accepted \\
Hypothesis 2 & PU & $<-$ & BCS & 0.222 & 0.038 & 5.823 & 0.000 & Accepted \\
Hypothesis 3 & PEU & $<-$ & MRS & 0.124 & 0.028 & 4.367 & 0.000 & Accepted \\
Hypothesis 4 & PU & $<-$ & MRS & 0.003 & 0.027 & 0.124 & 0.901 & Rejected \\
Hypothesis 5 & BCS & $<-$ & MRS & 0.437 & 0.027 & 16.218 & 0.000 & Accepted \\
Hypothesis 6 & WBS & $<-$ & MRS & 0.532 & 0.027 & 19.411 & 0.000 & Accepted \\
Hypothesis 7 & PEU & $<-$ & WBS & 0.107 & 0.039 & 2.720 & 0.007 & Accepted \\
Hypothesis 8 & PU & $<-$ & WBS & 0.058 & 0.037 & 1.569 & 0.117 & Rejected \\
Hypothesis 9 & PU & $<-$ & PEU & 0.605 & 0.036 & 16.983 & 0.000 & Accepted \\
Hypothesis 10 & ATT & $<-$ & PEU & 0.350 & 0.047 & 7.443 & 0.000 & Accepted \\
Hypothesis 11 & SIU & $<-$ & PEU & 0.309 & 0.042 & 7.446 & 0.000 & Accepted \\
Hypothesis 12 & ATT & $<-$ & PU & 0.543 & 0.041 & 13.191 & 0.000 & Accepted \\
Hypothesis 13 & SIU & $<-$ & PU & 0.267 & 0.039 & 6.793 & 0.000 & Accepted \\
Hypothesis 14 & SIU & $<-$ & ATT & 0.368 & 0.033 & 11.304 & 0.000 & Accepted \\
\hline
\end{tabular}

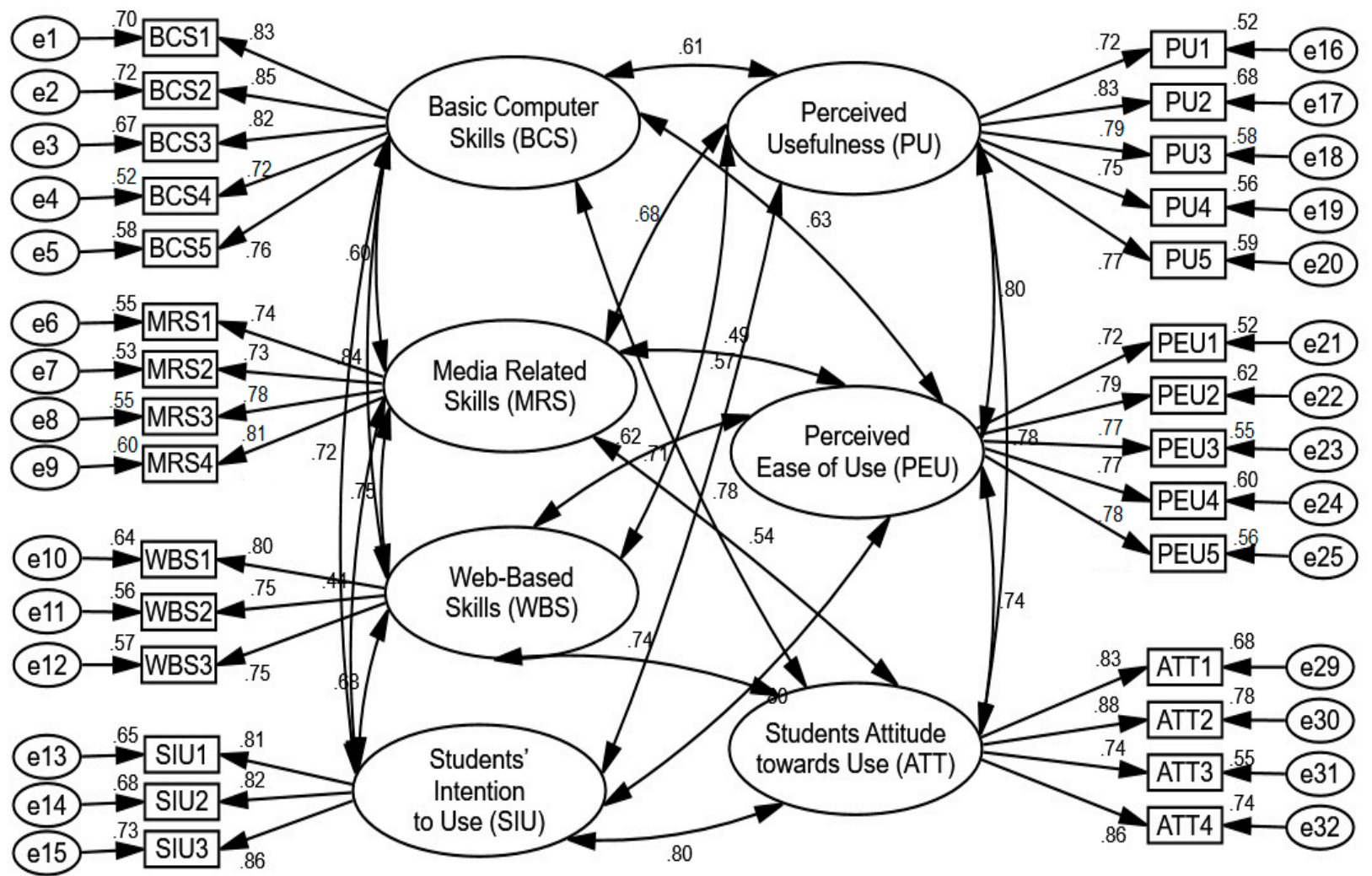

Figure 2. Measurement Model.

\subsection{Path Coefficient and Structural Model}

The structural model specifies both the interaction and the influence of independent factors on the dependent variable (path coefficient). The maximum likelihood technique, in particular, may be used to thoroughly examine complex models and uncover various correlations between multi-item elements, as well as the influence of moderating and mediating factors [47]. Figures 3 and 4 show the direct influence of the route coefficient on the latent predictor variable anticipated variables. 


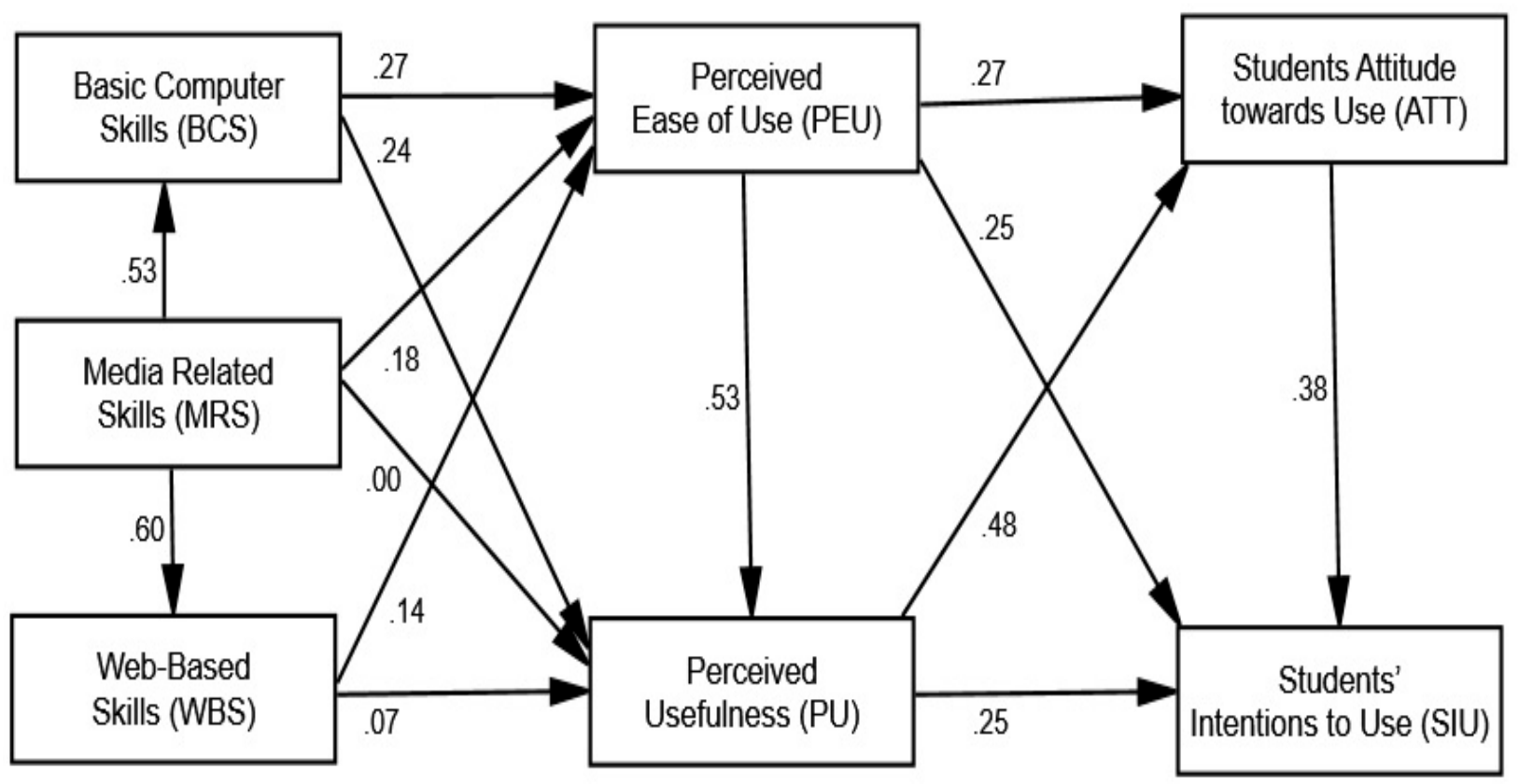

Figure 3. Path coefficient.

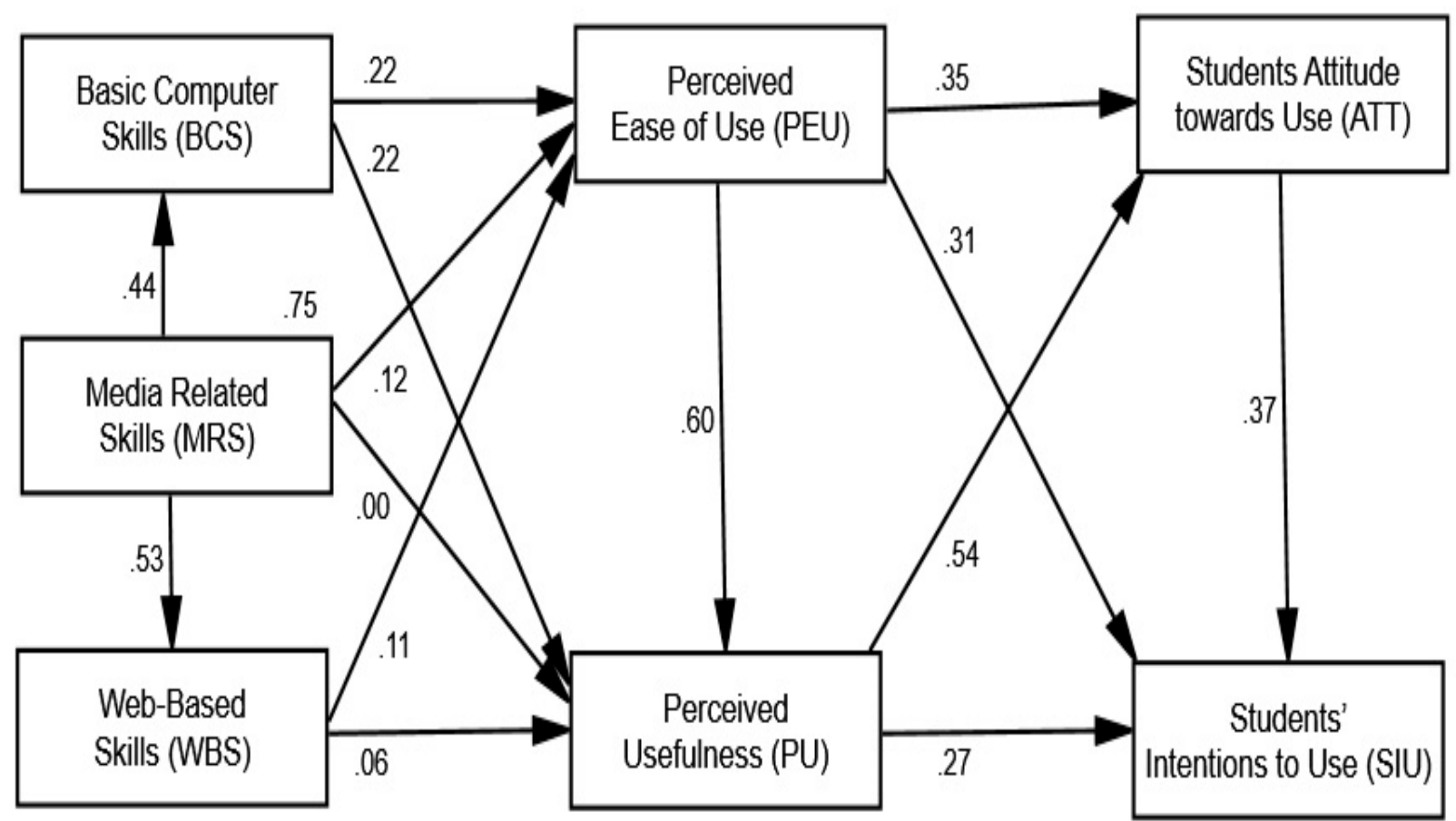

Figure 4. Structural model ( $p$ Value).

Table 5 demonstrates that $\mathrm{BCS}(\beta=0.223, \mathrm{CR}=5.576)$ has a positive and important impact on PEU, which supports Hypothesis 1 . Hypothesis 2 confirms that BCS $(\beta=0.222$, $C R=5.823$ ) has a positive and important impact on PU. Hypothesis 3 confirms that MRS $(\beta=0.124, C R=4.367)$ has a positive and important impact on PEU. However, MRS ( $\beta=0.003, C R=0.124$ ) has a negative impact on PU, contradicting Hypothesis 4 . Furthermore, MRS ( $\beta=0.437, C R=16.218)$ has a positive and significant effect on BCS; thus, Hypothesis 5 is accepted. Similarly, MRS $(\beta=0.532, C R=19.411)$ has a positive and significant effect on WBS; thus, Hypothesis 6 is accepted. WBS ( $\beta=0.107, C R=2.720)$ has a positive and significant effect on PEU; thus, Hypothesis 7 is accepted. However, 
WBS ( $\beta=0.058, C R=1.569)$ has a positive and significant effect on PU, which means that Hypothesis 8 is rejected. PEU ( $\beta=0.605, C R=16.983)$ has a positive and significant effect on PU; thus, Hypothesis 9 is accepted. Moreover, PEU ( $\beta=0.350, C R=7.443)$ has a positive and significant effect on students' ATT; thus, Hypothesis 10 is accepted. PEU ( $\beta=0.309$, $\mathrm{CR}=7.446$ ) has a positive and significant effect on SIU ICT for digital learning; thus, $\mathrm{Hy}$ pothesis 11 is accepted. $\mathrm{PU}(\beta=0.543, C R=13.191)$ has a positive and significant effect on students' ATT-ICT; thus, Hypothesis 12 is accepted. Moreover, PU ( $\beta=0.267, C R=6.793)$ has a positive and significant effect on SIU ICT for digital learning; thus, Hypothesis 13 is accepted. Finally, students' ATT-ICT ( $\beta=0.368, C R=11.304$ ) has a positive and significant effect on SIU ICT for digital learning; thus, Hypothesis 14 is accepted.

\section{Description and Analysis of Factors}

The standard deviation (SD) and mean (mean) are two statistics that illustrate how measurements in a population differ from the average (mean) or expected value. The bulk of the data points are similar to the mean when the standard deviation is low. The data is distributed if the standard deviation is substantial. As a consequence, as shown in Tables 6-12, all values were embraced, demonstrating that university students' usage of accessible ICTs aided their digital learning. "Strongly disagree" is number one, "disagree" is number two, "neutral" is number three, "agree" is number four, and "strongly agree" is number five. According to data, the majority of students support or strongly agree with fundamental computer abilities, as well as its perceived worth and ease of use. As a result, fundamental computer skills are defined in this study as a student's perception that using ICT would improve their digital learning (see Table 6).

Table 6. Measuring BCS.

\begin{tabular}{|c|c|c|c|c|c|c|c|c|}
\hline Factor & Code & \multicolumn{5}{|c|}{ Numbers and Percentages of Respondents } & \multirow{2}{*}{$\frac{\text { Mean }}{4.43}$} & \multirow{2}{*}{$\frac{\text { SD }}{0.824}$} \\
\hline \multirow{5}{*}{ BCS } & BCS1 & $9(1.3)$ & $13(1.8)$ & $61(8.6)$ & $211(29.7)$ & $417(58.6)$ & & \\
\hline & BCS2 & $8(1.1)$ & $14(2.0)$ & $42(5.9)$ & $202(28.4)$ & $445(62.6)$ & 4.49 & 0.789 \\
\hline & BCS3 & $15(2.1)$ & $14(2.0)$ & $58(8.2)$ & $188(26.4)$ & $436(61.3)$ & 4.43 & 0.883 \\
\hline & BCS4 & $23(3.2)$ & $44(6.2)$ & $118(16.6)$ & $226(31.8)$ & $300(42.2)$ & 4.04 & 1.062 \\
\hline & BCS5 & $7(1.0)$ & $15(2.1)$ & $51(7.2)$ & $194(27.3)$ & $444(62.4)$ & 4.48 & 0.799 \\
\hline
\end{tabular}

Table 7. Measuring MRS.

\begin{tabular}{|c|c|c|c|c|c|c|c|c|}
\hline Factor & Code & \multicolumn{5}{|c|}{ Numbers and Percentages of Respondents } & \multirow{2}{*}{\begin{tabular}{|c|} 
Mean \\
3.86
\end{tabular}} & \multirow{2}{*}{$\begin{array}{c}\text { SD } \\
1.094\end{array}$} \\
\hline \multirow{4}{*}{ Media Related Skills } & MRS1 & $21(3.0)$ & $76(10.7)$ & $125(17.6)$ & $245(34.5)$ & $244(34.3)$ & & \\
\hline & MRS2 & $16(2.3)$ & $56(7.9)$ & $118(16.6)$ & $233(32.8)$ & $288(40.5)$ & 4.01 & 1.044 \\
\hline & MRS3 & $13(1.8)$ & $31(4.4)$ & $79(11.1)$ & $248(34.9)$ & $340(47.8)$ & 4.23 & 0.937 \\
\hline & MRS4 & $86(12.1)$ & $130(18.3)$ & $151(21.2)$ & $173(24.3)$ & $171(24.1)$ & 3.30 & 1.336 \\
\hline
\end{tabular}

Table 8. Measuring WBS.

\begin{tabular}{ccccccccc}
\hline Factor & Code & \multicolumn{4}{c}{ Numbers and Percentages of Respondents } & Mean & SD \\
\hline \multirow{3}{*}{ Web-Based Skills } & WBS1 & $15(2.1)$ & $28(3.9)$ & $54(7.6)$ & $247(34.7)$ & $367(51.6)$ & 4.30 & 0.923 \\
& WBS2 & $18(2.5)$ & $32(4.5)$ & $81(11.4)$ & $252(35.4)$ & $328(46.1)$ & 4.18 & 0.975 \\
& WBS3 & $8(1.1)$ & $18(2.5)$ & $47(6.6)$ & $220(30.9)$ & $418(58.8)$ & 4.44 & 0.816 \\
\hline
\end{tabular}

Table 9. Measuring PEU.

\begin{tabular}{|c|c|c|c|c|c|c|c|c|}
\hline Factor & Code & \multicolumn{5}{|c|}{ Numbers and Percentages of Respondents } & Mean & SD \\
\hline \multirow{5}{*}{ Perceived Ease of Use } & PEU1 & $4(0.6)$ & $29(4.1)$ & $71(10.0)$ & $304(42.8)$ & $303(42.6)$ & 4.23 & 0.830 \\
\hline & PEU2 & $4(0.6)$ & $17(2.4)$ & $53(7.5)$ & $286(40.2)$ & $351(49.4)$ & 4.35 & 0.768 \\
\hline & PEU3 & $6(0.8)$ & $46(6.5)$ & $100(14.1)$ & $304(42.8)$ & $255(35.9)$ & 4.06 & 0.912 \\
\hline & PEU4 & $9(1.3)$ & $28(3.9)$ & $59(8.3)$ & $279(39.2)$ & $336(47.3)$ & 4.27 & 0.868 \\
\hline & PEU5 & $7(1.0)$ & $14(2.0)$ & $47(6.6)$ & $246(34.6)$ & $397(55.8)$ & 4.42 & 0.783 \\
\hline
\end{tabular}


Table 10. Measuring PU.

\begin{tabular}{ccccccccc}
\hline Factor & Code & \multicolumn{5}{c}{ Numbers and Percentages of Respondents } & Mean & SD \\
\hline & PU1 & $10(1.4)$ & $19(2.7)$ & $43(6.0)$ & $267(37.6)$ & $372(52.3)$ & 4.37 & 0.827 \\
Perceived & PU2 & $4(0.6)$ & $6(0.8)$ & $38(5.3)$ & $251(35.3)$ & $412(57.9)$ & 4.49 & 0.690 \\
Usefulness & PU3 & $12(1.7)$ & $18(2.5)$ & $76(10.7)$ & $219(30.8)$ & $386(54.3)$ & 4.33 & 0.890 \\
& PU4 & $11(1.5)$ & $14(2.0)$ & $75(10.5)$ & $246(34.6)$ & $365(51.3)$ & 4.32 & 0.857 \\
& PU5 & $11(1.5)$ & $41(5.8)$ & $84(11.8)$ & $256(36.0)$ & $319(44.9)$ & 4.17 & 0.954 \\
\hline
\end{tabular}

Table 11. Measuring students' ATT.

\begin{tabular}{|c|c|c|c|c|c|c|c|c|}
\hline Factor & Code & \multicolumn{5}{|c|}{ Numbers and Percentages of Respondents } & Mean & SD \\
\hline \multirow{4}{*}{$\begin{array}{l}\text { Students' Attitude } \\
\text { towards Use }\end{array}$} & ATT1 & $9(1.3)$ & $7(1.0)$ & $58(8.2)$ & $249(35.0)$ & $388(54.6)$ & 4.41 & 0.785 \\
\hline & ATT2 & $10(1.4)$ & $15(2.1)$ & $58(8.2)$ & $244(34.3)$ & $384(54.0)$ & 4.37 & 0.833 \\
\hline & ATT3 & $15(2.1)$ & $27(3.8)$ & $87(12.2)$ & $225(31.6)$ & $357(50.2)$ & 4.24 & 0.954 \\
\hline & ATT4 & $11(1.5)$ & $21(3.0)$ & $69(9.7)$ & $239(33.6)$ & $371(52.2)$ & 4.32 & 0.881 \\
\hline
\end{tabular}

Table 12. Measuring SIU ICT.

\begin{tabular}{|c|c|c|c|c|c|c|c|c|}
\hline Factor & Code & \multicolumn{5}{|c|}{ Numbers and Percentages of Respondents } & Mean & SD \\
\hline \multirow{3}{*}{$\begin{array}{c}\text { Students' Intentions } \\
\text { to Use }\end{array}$} & SIU1 & $12(1.7)$ & $7(1.0)$ & $40(5.6)$ & $277(39.0)$ & 375 (52.7) & 4.40 & 0.784 \\
\hline & SIU2 & $8(1.1)$ & $18(2.5)$ & $42(5.9)$ & $256(36.0)$ & $387(54.4)$ & 4.40 & 0.804 \\
\hline & SIU3 & $10(1.4)$ & $18(2.5)$ & $61(8.6)$ & $261(36.7)$ & $361(50.8)$ & 4.33 & 0.845 \\
\hline
\end{tabular}

The final results of MRS are shown in Table 7, which suggest that the majority of students agree with and highly support media-related abilities, as well as its perceived value and ease of use. As a result, in this study, media-related abilities are defined as a student's belief that utilizing ICT would help them improve their digital learning (see Table 7).

The final measurement findings of WBS are shown in Table 8, which demonstrate that the majority of students agree or strongly agree that WBS is beneficial and simple to apply. As a consequence, WBS is defined in this study as a student's belief that using ICT would assist them in improving their digital learning (see Table 8).

According to Table 9, majority of the students agree or strongly agree on PEU with perceived usefulness, students' opinions regarding utilization, and SIU ICT for digital learning. As a result, in this study, PEU is defined as a student's opinion that using ICT would help them improve their digital learning (see Table 9).

Table 10 shows the measurement results of PU, which reveal that most students agree or strongly agree on perceived usefulness, attitudes toward usage, and plans to use ICT for digital learning. As a result, in this study, PU is defined as a student's perception that using ICT would help them improve their digital learning (see Table 10).

The evaluation findings of ATT are shown in Table 11, which demonstrate that the majority of students agree or strongly agree with their opinions on using ICT for digital learning. As a result, a student's attitude toward ICT use is defined in this study as the degree to which the student feels that utilizing ICT will improve their digital learning (see Table 11).

The survey's results on SIU ICT are shown in Table 12; a great majority of students agree or strongly agree that ICT would benefit digital learning. As a result, students' intentions to utilize ICT in this study are defined as the extent to which they feel utilizing ICT will help them with their digital learning (see Table 12).

\subsection{Discussion and Consequences}

This is one of the first studies to utilize the TAM model to investigate ICT use for digital learning. Fundamental computing abilities, media-related skills, and WBS all have a substantial influence on PEU and utility, according to the given model. Students' attitudes toward and plans to use ICT for digital learning were similarly influenced by PEU and 
perceived usefulness. A total of 73.8 percent of students showed different attitudes about using ICT for digital learning, and 81.4 percent had different intentions to use ICT for educational technologies. The findings backed up the hypotheses that had been stated and the study methodology that had been constructed.

The results show how the TAM components of the BCS, MRS, and WBS (independent variables) are used to measure students' attitudes about ICT usage and intentions to use ICT for digital learning, as well as PEU and utility (mediating variables). Many categories were discovered to have a positive and relevant connection with students' attitudes about using ICT for digital learning, including core computer abilities, MRS, WBS, PU, and PEU. BCS, MRS, WBS, PEU, PU, students' ATT use, and students' intentions to utilize ICT for digital learning have all been shown to have substantial advantages in past research. As a result of these findings, students should evaluate the potential of ICT to match their study goals and identify essential computer abilities, such as MRS, WBS, PEU, and PU, before deciding to utilize it for digital learning.

Students' ATT ICT for digital learning, as well as their plans to use ICT for digital learning, were also investigated. Students are more likely to think about technology than adults. When they identify SIU ICT for digital learning, they want it to be simple to use and beneficial, and they want it to be able to satisfy those needs [48-51]. The use of ICT for digital learning is well known and widely employed in education, particularly among students who are already tech-savvy. It demonstrates that students' views about adopting ICT for digital learning are influenced by their BCS, MRS, WBS, PEU, and PU.

Table 4 shows the statistical analysis findings, which demonstrate that all of the hypothesized relationships were proven valid. Some of the hypothesis findings ran counter to prior studies, such as [36], which found that basic computer skills had a large and favorable influence on PU. More study into the link between the components is needed as a result of the inconsistent results. In addition, BCS, MRS, and WBS all had a good impact on PEU and PU, as well as students' attitudes and intentions about using ICT for digital learning.

Previous research $[36,49,51,52]$ supports this result. PEU and PU have a favorable and explicit effect on students' attitudes toward and plans to use ICT for digital learning, according to the TAM. This was shown in this research, which discovered that higher PEU and PU resulted in enhanced student attitudes about utilizing ICT, as well as increased students' intentions to use ICT for digital learning. Other research back up this study's conclusion that PEU and PU have a significant and direct relationship [53,54]. Furthermore, according to this research, students say ICT is straightforward to use if it benefits their academics. Students who have the opportunity to use ICT are more likely to regard technology as straightforward and useful.

As a result, in order to improve PEU, ICT developers should create systems that are both user-friendly and vital to the long-term success of student education. Managers may be able to assist students in determining how to use ICT for digital learning. Consumer expectations and values should be taken into account by ICT developers, designers, and purchasers (such as higher education institutions), according to the findings, to ensure that the structure can meet student requests. This idea of a good fit between system attributes and student goals will help with ICT uptake in educational contexts. The BCS, MRS, and WBS all have an impact on students' attitudes toward and willingness to use ICT for digital learning.

According to the findings, PEU affected PU, with both belief constructs and future intents to use ICT for digital learning functioning as drivers of students' attitudes toward usage. To put it another way, ICT for digital learning must be simple to use and advantageous to university students. ICT should be easy to use and give detailed instructions. The findings also showed how important it is for professors to describe how students should use ICT to study course content, because students' attitudes toward using ICT have an influence on their intents to use ICT for digital learning. 
According to this survey, using ICT for digital learning through fundamental computer skills, media-related skills, and WBS has an influence on PEU and PU. The PEU and PU of ICT impact students' attitudes toward technology, as well as their intents to utilize it for digital learning. The findings contribute significantly to the TAM in terms of educational sustainability and the use of ICT for digital learning [21,36,49,51,52,55]. As ICT becomes more commonly utilized as an educational medium, many of the strategies employed in the learning process for both instructors and students are rising and will undoubtedly continue to increase [56].

The use of ICT under the novel approach of the managing emotions and motivational processes, contributing to meaningful learning in students [57]. On the other hand, ICTs offer enormous potential in terms of their application in the field of education such as the contributions of neuro-education [58]. This is consistent with previous studies by $[59,60]$, which found that both perceived ease of use and perceived usefulness affect students' attitude towards using and intention to use distance learning. Therefore, in the following methods, this study varies from previous research. First, this study aims to combine the IS output model and the TAM into a unified model for ICT use as a source of educational sustainability. Second, unlike previous research in Saudi Arabia, such as $[38,39,43]$, this study aims to provide a comprehensive review of recent publications in the field of ICT use as a source of sustainability in higher education. Third, unlike prior studies that only looked at the effects of variables on intention to use, this study looks at the effects of variables on ATT and SIU as well. As a result, the current study is likely to provide a wide range of outcomes and provide crucial information about students' behavior, such as their ATT and SIU. BCS, MRS, and WBS had a significant relationship influence on PEU and PU, which influenced ATT and SIU at two Saudi public universities.

During the worldwide lockdown and transition to online learning, students were most satisfied with the support provided by teaching staff and their universities' public relations [61]. However, students received inadequate social support and security protection from others and their instructors when they needed it [62]. Thus, higher education institutions must ensure inclusive, equitable, and quality education that reduces the digital divide, promoting sustainable activities $[63,64]$. Furthermore, readily available ICTs can assist instructors and students in resolving problems, learning about current events, and boosting global communication and competitiveness [65], all of which are outcomes of our research. Last but not least, here are the scientific contributions:

1. Students' attitudes toward technology and enthusiasm to utilize it for digital learning can be improved by incorporating ICT into instructional practices. Lecturers and supervisors should encourage students to use ICT to solve problems, convey information, and exchange knowledge in order to increase their learning, success, and research abilities.

2. It is suggested that higher education institutions should encourage students who have prior classroom experience with ICT rather than put pressure on those who do not. In this approach, students integrate ICT components and resources into their learning process.

3. Students' attitudes about using ICT for digital learning, as well as their intents to do so, are influenced by both technology and resources. Students should take use of ICT-based digital learning options.

\subsection{Limitations of Research}

This study has its own limits, regardless of the insights it delivers. First and foremost, because this study only looked at two colleges, the findings should be interpreted with caution, as behavior at other universities (both private and public) may differ. Another disadvantage is that this study focuses on quantitative data; as a result, researchers should employ qualitative data (interviews or observations) to prevent finding contradictions across research themes. In order to address weaknesses and widen the range of its conclusions, future research should duplicate this investigation in different regions, nations, 
and cultures. Age and gender impacts were not explored since a moderator study was not possible owing to the limited sample size. To analyze the effect of moderators on adoption in a broader study including many countries, institutions, or technologies, researchers used experimental power and data stability, as well as additional student satisfaction scores. Therefore, a qualitative analysis would be useful to deconstruct these variables to examine the similarities and contrasts between the many viewpoints of the unified theory of acceptance and usage of technological components by context. More work is needed to adapt the findings to other circumstances, examine the model's breadth of applicability, and develop new applications after the TAM and IS Success Model were built and proven in this study. Extending the research to other technology-based fields including M-learning and E-learning system adoption, as well as E-readiness, with a larger research sample, aims to increase current understanding of IS application use.

\subsection{Conclusions and Future Work}

In addition to data on student perceptions of utilizing ICT for digital learning, the TAM model was verified in terms of educational sustainability. Theoretical and practical implications of the work were examined. The benefits of the TAM were highlighted in this article, along with fresh information on user adoption and the use of ICT for digital learning. In the twenty-first century, ICT plays a vital role in improving the quality of learning and study activities, not just for high school students, but also for university students. However, no prior study has looked at students' perceptions of ICT and their plans to use it for digital learning. Here, the TAM has been shown to be sufficiently robust to offer findings on the phenomena under investigation, namely, students' attitudes toward ICT adoption and plans to utilize ICT for educational purposes. This research contributes significantly by assisting researchers, practitioners, system developers, service providers, vendors, and academics in recognizing systematic research approaches for model validation in education sustainability, especially when modeling structural equations in the field of mathematics using ICT for digital learning. This study incorporated seven innovative TAM model characteristics as critical variables of ICT adoption for digital learning. Furthermore, the research model considers the interactions among the following factors: BCS, MRS, WBS, PEU, PU, students' attitudes about ICT use, and students' plans to use ICT for digital learning. The literature's mixed findings imply that additional research into the relationship between media-related and web-based talents and PU is needed. Given the study's limitations and qualitative approaches, future research should focus on interviewing students and educators to understand more about their perspectives on using ICT for digital learning. Future research should look at these difficulties by cross-validating them using this model and considering cultural factors.

Author Contributions: Conceptualization, A.M.S., M.A.A., M.M.A. and W.M.A.; methodology, A.M.S., M.A.A., M.M.A. and W.M.A.; software, M.M.A. and W.M.A.; validation, A.M.S., M.A.A. and W.M.A.; formal analysis, M.A.A. and W.M.A.; investigation, A.M.S., M.A.A., M.M.A. and W.M.A.; resources, A.M.S., M.A.A., M.M.A. and W.M.A.; data curation, A.M.S., M.A.A., M.M.A. and W.M.A.; writing—original draft preparation, A.M.S., M.A.A., M.M.A. and W.M.A.; writingreview and editing, A.M.S., M.A.A., M.M.A. and W.M.A.; visualization, A.M.S., M.A.A., M.M.A. and W.M.A.; supervision, A.M.S., M.A.A., M.M.A. and W.M.A.; project administration, A.M.S. and M.A.A.; funding acquisition, A.M.S. and M.A.A. All authors have read and agreed to the published version of the manuscript.

Funding: The authors extend their appreciation to the Deputyship for Research \& Innovation, Ministry of Education in Saudi Arabia for funding this research work through the project number (UB-01-1442).

Institutional Review Board Statement: No applicable.

Informed Consent Statement: No applicable.

Data Availability Statement: No applicable.

Conflicts of Interest: The authors declare no conflict of interest. 


\section{References}

1. Haydn, T.; Barton, R. First do no harm: Factors influencing teachers' ability and willingness to use ICT in their subject teaching. Comput. Educ. 2008, 51, 439-447. [CrossRef]

2. Zhao, Y.; Tan, H.; Mishra, P. Teaching and learning: Whose computer is it? J. Adolesc. Adult Lit. 2001, 44, 348-355.

3. Tubin, D. Typology of ICT implementation and technology application. Comput. Sch. 2006, 23, 85-98. [CrossRef]

4. Hermans, R.; Tondeur, J.; van Braak, J.; Valcke, M. The impact of primary school teachers' educational beliefs on the classroom use of computers. Comput. Educ. 2008, 51, 1499-1509. [CrossRef]

5. Muñoz-Miralles, R.; Ortega-González, R.; López-Morón, M.R.; Batalla-Martínez, C.; Manresa, J.M.; Montellà-Jordana, N.; ToránMonserrat, P. The problematic use of Information and Communication Technologies (ICT) in adolescents by the cross sectional JOITIC study. BMC Pediatrics 2016, 16, 140. [CrossRef]

6. Ferro, C.; Martínez, A.I.; del Otero, M.C. Ventajas del uso de las TICs en el proceso de enseñanza-aprendizaje desde la óptica de los docentes universitarios españoles. Rev. Electron. Tecnol. Educ. 2009, 29, 1-12. [CrossRef]

7. Orellana, N.; Bo, R.; Belloch, C.; Aliaga, F. Estilos de Aprendizaje y Utilización de las TIC en la Enseñanza Superior. 2010. Available online: http:/ / reposital.cuaed.unam.mx:8080/jspui/handle/123456789/2563 (accessed on 7 July 2021).

8. Echeverría, A.C. Usos De Las Tic En La Docencia Universitaria: Opinión Del Profesorado De Educación Especial. Rev. Electron. Actual. Investig. Educ. 2014, 14, 1-24.

9. Yazon, J.M.O.; Mayer-Smith, J.A.; Redfield, R.J. Does the medium change the message? The impact of a web-based genetics course on university students' perspectives on learning and teaching. Comput. Educ. 2002, 38, 267-285. [CrossRef]

10. Prendes-Espinosa, M.P.; Castañeda-Quintero, L.; Gutiérrez-Porlán, I. ICT competences of future teachers. Comunicar 2010, 18 175-182. [CrossRef]

11. Fernández, J.C.; Fernández, M.C.; Cebreiro, B. Desarrollo de un cuestionario de competencias en TIC para profesores de distintios niveles educativos. Rev. De Medios Y Educ. 2016, 48, 135-148.

12. Lareki, A.; Martínez, J.I.; Amenabar, N. Towards an efficient training of university faculty on ICTs. Comput. Educ. 2010, 54, 491-497. [CrossRef]

13. Al-Rahmi, A.M.; Al-Rahmi, W.M.; Alturki, U.; Aldraiweesh, A.; Almutairy, S.; Al-Adwan, A.S. Exploring the Factors Affecting Mobile Learning for Sustainability in Higher Education. Sustainability 2021, 13, 7893. [CrossRef]

14. Sayaf, A.M.; Alamri, M.M.; Alqahtani, M.A.; Al-Rahmi, W.M. Information and Communications Technology Used in Higher Education: An Empirical Study on Digital Learning as Sustainability. Sustainability 2021, 13, 7074. [CrossRef]

15. Cabero-Almenara, J.; Morales-Lozano, J.A.; Osuna, J.B.; Fernández-Batanero, J.M.; Tena, R.R.; Román-Graván, P.; BallesterosRegaña, C. Análisis de centros de recursos de producción de las TIC de las universidades españolas. Rev. Educ. 2010, 351, 237-257. Available online: https: / / dialnet.unirioja.es/servlet/articulo?codigo=3123681 (accessed on 7 July 2021).

16. Harianto, I.; Hidayat, A.; Koes, S. Analisis Perencanaan Pembelajaran Guru Fisika SMA dalam Mengintegrasikan Keterampilan Berpikir Kreatif Siswa. Semin. Pendidik. IPA Pascasarj. UM 2016, 1, 301-307.

17. Wijaya, E.Y.; Sudjimat, D.A.; Nyoto, A. Transformasi Pendidikan Abad 21 Sebagai Tuntutan Pengembangan Sumber Daya manusia Di Era Global. Pros. Semin. Nas. Pendidik. Mat. 2016, 1, 263-278.

18. Karseth, B.; Sivesind, K. Conseptualising curriculum knowledge within and beyond the national context. Eur. J. Educ. 2010, 45, 103-120. [CrossRef]

19. Al-Rahmi, W.M.; Yahaya, N.; Alturki, U.; Alrobai, A.; Aldraiweesh, A.A.; Omar Alsayed, A.; Kamin, Y.B. Social media-based collaborative learning: The effect on learning success with the moderating role of cyberstalking and cyberbullying. Interact. Learn. Environ. 2020, 9, 1-14. [CrossRef]

20. Al-Gahtani, S.S. Empirical investigation of e-learning acceptance and assimilation: A structural equation model. Appl. Comput. Inform. 2016, 12, 27-50. [CrossRef]

21. Davis, F.D.; Bagozzi, R.P.; Warshaw, P.R. User acceptance of computer technology: A comparison of two theoretical models. Manag. Sci. 1989, 35, 982-1003. [CrossRef]

22. BGT. Crunched by the Numbers: Digital Skills Gap in the Workforce. Burning Glass Technologies Report. 2015. Available online: http:/ /hdl.voced.edu.au/10707/372822 (accessed on 7 July 2021).

23. Hussain, M.A.; Farooq, M.S. Practices and barriers in computer technology skills: Portraying student teachers of open and distance learning. Pak. J. Distance Online Learn. 2016, 1, 25-38.

24. Soenhadji, I.M.; Chodijah, S. Sikap dan Pengalaman Mahasiswa dalam Menggunakan Komputer serta Pengaruhnya Terhadap Computer Self Efficacy (CSE). Proceeding Seminar Nasional KOMMIT; 2006, pp. 1411-6286. Available online: https: / /repository. ar-raniry.ac.id/id/eprint/3925/1/Nurul\%20Aini.pdf (accessed on 7 July 2021).

25. Prensky, M. Digital natives, digital immigrants part 2: Do they really think differently? Horizon 2001, 9, 1-6. [CrossRef]

26. Şahin, M.C. Yeni binyılın öğrencilerinin özellikleri. Anadolu Univ. J. Soc. Sci. 2009, 9, 155-172.

27. Livingstone, S. The Changing Nature and Uses of Media Literacy; MEDIA@LSE Electronic Working Papers; London School of Economics and Political Science: London, UK, 2003; p. 4.

28. Guo, L.; McCombs, M. Network Agenda Setting: A third Level of Media Effects. In Proceedings of the Annual Meeting of the International Communication Association, Boston, MA, USA, 2011. Available online: http://www.leiguo.net/publications/guo_ nas_2011_ica.pdf (accessed on 7 July 2021).

29. Eyal, L. Digital assessment literacy: The core role of the teacher in a digital environment. Educ. Technol. Soc. 2012, 15, 37-49. 
30. Soussi, K. Professional Development in Higher Education: Participation, Impact and Needs. The Case of Mohamed V University Abu Dhabi. J. Knowl. Humanit. 2019, 1, 300.

31. Erdoğan, Y.; Bayram SDeniz, L. Web tabanlı öğretim tutum ölçeği: Açıklayıcı ve doğrulayıcı faktör analizi çalışması. Uluslararası Insan Bilimleri Derg. 2007, 4, 1-14.

32. Kay, R.H.; Knaack, L. Analyzing the effectiveness of learning objects for secondary school science classrooms. J. Educ. Multimed. Hypermedia 2009, 18, 113-135.

33. Nurmi, S.; Jaakkola, T. Effectiveness of learning objects in various instructional settings. Learn. Media Technol. 2006, 31, 233-247. [CrossRef]

34. Lowe, K.; Lee, L.; Schibeci, R.; Cummings, R.; Phillips, R.; Lake, D. Learning objects and engagement of students in Australian and New Zealand schools. Br. J. Educ. Technol. 2010, 41, 227-241. [CrossRef]

35. Al-Rahmi, W.M.; Alzahrani, A.I.; Yahaya, N.; Alalwan, N.; Kamin, Y.B. Digital communication: Information and communication technology (ICT) usage for education sustainability. Sustainability 2020, 12, 5052. [CrossRef]

36. Teo, T.; Zhou, M. Explaining the intention to use technology among university students: A structural equation modeling approach. J. Comput. High. Educ. 2014, 26, 124-142. [CrossRef]

37. Venkatesh, V.; Morris, M.G.; Davis, G.B.; Davis, F.D. User acceptance of information technology: Toward a unified view. MIS Q. 2003, 27, 425-478. [CrossRef]

38. Alamri, M.M.; Almaiah, M.A.; Al-Rahmi, W.M. Social media applications affecting Students' academic performance: A model developed for sustainability in higher education. Sustainability 2020, 12, 6471. [CrossRef]

39. Alamri, M.M.; Almaiah, M.A.; Al-Rahmi, W.M. The role of compatibility and task-technology fit (TTF): On social networking applications (SNAs) usage as sustainability in higher education. IEEE Access 2020, 8, 161668-161681. [CrossRef]

40. Fabunmi, M.P.B.A.; Isaiah, A.A. Class factors as determinants of secondary school student's academic performance in Oyo State, Nigeria. J. Soc. Sci. 2007, 14, 243-247. [CrossRef]

41. Riaz, A.; Riaz, A.; Hussain, M. Students' acceptance and commitment to e- learning: Evidence from Pakistan. J. Educ. Soc. Res. 2011, 1, 21-30.

42. Tan, P.J.B. An empirical study of how the learning attitudes of college students toward English e-tutoring websites affect site sustainability. Sustainability 2019, 11, 1748. [CrossRef]

43. Alyoussef, I.Y.; Alamri, M.M.; Al-Rahmi, W.M. Social media use (SMU) for teaching and learning in Saudi Arabia. Int. J. Recent Technol. Eng. 2019, 8, 942-946.

44. Venkatesh, V.; Thong, J.Y.; Xu, X. Consumer acceptance and use of information technology: Extending the unified theory of acceptance and use of technology. MIS Q. 2012, 36, 157-178. [CrossRef]

45. Al-Rahmi, W.M.; Yahaya, N.; Alamri, M.M.; Alyoussef, I.Y.; Al-Rahmi, A.M.; Kamin, Y.B. Integrating innovation diffusion theory with technology acceptance model: Supporting students' attitude towards using a massive open online courses (MOOCs) systems. Interact. Learn. Environ. 2019, 7, 1-13. [CrossRef]

46. Hair, J.F., Jr.; Babin, B.J.; Krey, N. Covariance-based structural equation modeling in the Journal of Advertising: Review and recommendations. J. Advert. 2017, 46, 163-177. [CrossRef]

47. Berraies, S.; Yahia, K.B.; Hannachi, M. Identifying the effects of perceived values of mobile banking applications on customers Int. J. Bank Mark. 2017, 35, 1018-1038. [CrossRef]

48. Fan, R.J.D.; Tan, P.J.B. Application of Information Technology in Preschool Aesthetic Teaching from the Perspective of Sustainable Management. Sustainability 2019, 11, 2179. [CrossRef]

49. Teo, T. Modelling technology acceptance in education: A study of pre-service teachers. Comput. Educ. 2009, 52, 302-312. [CrossRef]

50. Ullah, N.; Mugahed Al-Rahmi, W.; Alzahrani, A.I.; Alfarraj, O.; Alblehai, F.M. Blockchain Technology Adoption in Smart Learning Environments. Sustainability 2021, 13, 1801. [CrossRef]

51. Macharia, J.K.N.; Pelser, T.G. Key factors that influence the diffusion and infusion of information and communication technologies in Kenyan higher education. Stud. High. Educ. 2012, 39, 695-709. [CrossRef]

52. Islam, A.A.; Mok, M.M.C.; Gu, X.; Spector, J.; Hai-Leng, C. ICT in Higher Education: An Exploration of Practices in Malaysian Universities. IEEE Acces 2019, 7, 16892-16908. [CrossRef]

53. Venkatesh, V.; Davis, F.D. A theoretical extension of the technology acceptance model: Four longitudinal field studies. Manag. Sci. 2000, 46, 186-204. [CrossRef]

54. Al-Adwan, A.S.; Yaseen, H.; Alsoud, A.; Abousweilem, F.; Al-Rahmi, W.M. Novel extension of the UTAUT model to understand continued usage intention of learning management systems: The role of learning tradition. Educ. Inf. Technol. 2021, 1-27. [CrossRef]

55. Al-Rahmi, A.M.; Shamsuddin, A.; Alturki, U.; Aldraiweesh, A.; Yusof, F.M.; Al-Rahmi, W.M.; Aljeraiwi, A.A. The Influence of Information System Success and Technology Acceptance Model on Social Media Factors in Education. Sustainability 2021, 13, 7770. [CrossRef]

56. Bala, M. Use of ICT in Higher Education. Multidisciplinary Higher Education. In Research Dynamics and Concepts; Swaranjali Publication: Perth, WA, Australia, 2018; pp. 368-376.

57. Espino-Díaz, L.; Fernandez-Caminero, G.; Hernandez-Lloret, C.-M.; Gonzalez-Gonzalez, H.; Alvarez-Castillo, J.-L. Analyzing the Impact of COVID-19 on Education Professionals. Toward a Paradigm Shift: ICT and Neuroeducation as a Binomial of Action Sustainability 2020, 12, 5646. [CrossRef]

58. Espino-Díaz, L.; Alvarez-Castillo, J.-L.; Gonzalez-Gonzalez, H.; Hernandez-Lloret, C.-M.; Fernandez-Caminero, G. Creating Interactive Learning Environments through the Use of Information and Communication Technologies Applied to Learning of Social Values: An Approach from Neuro-Education. Soc. Sci. 2020, 9, 72. [CrossRef] 
59. Rizun, M.; Strzelecki, A. Students' acceptance of the Covid-19 impact on shifting higher education to distance learning in Poland. Int. J. Environ. Res. Public Health 2020, 17, 6468. [CrossRef]

60. Agrawal, A.K.; Mittal, G.K. The Role of ICT in Higher Education. In Multidisciplinary Higher Education, Research, Dynamics and Concepts; Swaranjali Publication: Perth, WA, Australia, 2018; pp. 76-83.

61. Aristovnik, A.; Keržič, D.; Ravšelj, D.; Tomaževič, N.; Umek, L. Impacts of the COVID-19 pandemic on life of higher education students: A global perspective. Sustainability 2020, 12, 8438. [CrossRef]

62. Cifuentes-Faura, J.; Obor, D.O.; To, L.; Al-Naabi, I. Cross-cultural impacts of COVID-19 on higher education learning and teaching practices in Spain, Oman, Nigeria and Cambodia: A cross-cultural study. J. Univ. Teach. Learn. Pract. 2021, 18, 8. [CrossRef]

63. Faura-Martínez, U.; Lafuente-Lechuga, M.; Cifuentes-Faura, J. Sustainability of the Spanish university system during the pandemic caused by COVID-19. Educ. Rev. 2021, 1-19. [CrossRef]

64. Ali, W. Online and remote learning in higher education institutes: A necessity in light of COVID-19 pandemic. High. Educ. Stud. 2020, 10, 16-25. [CrossRef]

65. Dave, D.D. An Analytical Study of the Role of ICT in Higher Education. J. Glob. Econ. 2019, 15, 56-61. 